\title{
Ailenin Güçlendirilmesi ve Pediatri Hemşireliğinde Uygulanması
}

\author{
Pelin KARATAŞ*, Hüsniye ÇALIŞIR**, Seher SARIKAYA KARABUDAK***
}

$\ddot{O} z$

Derleme tipinde olan bu makalenin amacı aile ve hemşirelik bakımı açısından oldukça önemli olan ailenin güçlendirilmesinin önemini, aileye, çocuğa ve sağlık çalışanlarına olan yararlarını açıklamak, uygulama adımları ve pediatri hemşireliğinde uygulanmasına ilişkin somut öneriler sunmaktır. Ailenin stresli dönemlerinde içsel ve dışsal güçlerini ortaya çıkarmayı sağlayan ailenin güçlendirilmesi hem ailelere hem de hemşirelere olumlu katkıda bulunur. Hemşireler bakımlarında hastanın ve ailenin güçlü yanlarına odaklandıklarında güçlendirme temelli bakımı başlatmış olurlar. Ailenin güçlendirilmesini önemseyen ve bu amaçla aktif rol alan pediatri hemşireleri çocuk ve ailenin gelecek için umutlarını sürdürmelerine, gereksinimlerini karşılamaya, aile işlevselliğinin devamlılı̆̆ına, kaynaklara ve bilgiye ulaşmalarına yardımcı olur. Ayrıca bu yaklaşımı kullanan hemşireler, kendi benliklerini daha kolay bulur, meslekten ve yaşamdan daha fazla doyum alır, hasta ve ailesi hakkında daha kapsamlı veri toplar ve etkin bakım verir. Bu nedenle pediatri hemşirelerinin, bakım uygulamalarında ailenin güçlendirilmesi yaklaşımını benimsemeleri, ailenin güçlenmesini ölçmek için değerlendirme aracı geliştirmeleri ve bu konudaki bilgi ve deneyimlerini arttırmaları önerilir.

Anahtar Sözcükler: Aile, Çocuk, Ebeveyn, Güçlendirilme, Pediatri, Hemşire.

\section{Abstract \\ Family Empowerment and Use In Pediatric Nursing}

The aim of this review is to explain the importance of empowerment the family which is very important in terms of family and nursing care, the benefits to the family, the child and the health care workers, and to provide concrete suggestions for implementation steps and application in pediatric nursing. Empowering the family, which enables the elimination of internal and external forces during stressful periods of the family, contributes positively to both families and nurses. When nurses focus on the strengths of the patient and family in their care, they start empowerment-based care. Pediatric nurses, who take care of the empowerment of the family and play an active role for this purpose, help the child and the family to maintain their hopes for the future, to meet their needs, to maintain family functionality, to access resources and information. In addition, nurses using this approach find their own self more easily, get more satisfaction from the profession and life, collect more comprehensive data about the patient and family, and provide effective care. For this reason, it is recommended that pediatric nurses adopt the family empowerment approach in care practices, develop an assessment tool to measure family empowerment, and increase their knowledge and experience in this area.

Key Words: Family, Child, Parent, Empowerment, Pediatri, Nurse.

Geliş tarihi: 24.05.2019 Kabul tarihi: 03.06.2020

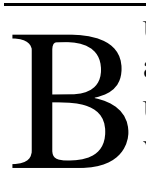

u derlemenin amacı aile ve hemşirelik bakımı açısından oldukça önemli olan ailenin güçlendirilmesinin önemini, aileye, çocuğa ve sağlık çalışanlarına olan yararlarını açıklamak, uygulama adımları ve pediatri hemşireliğinde uygulanmasına ilişkin somut öneriler sunmaktır. Toplumun en küçük yapı taşı olan aile, çocuğun fiziksel, psikolojik ve sosyal olarak gelişmesini sağlar $(1,2)$. Toplumda huzur ve refahın sağlanması için sağlıklı ve güçlü aileler oluşturulmaya çalışılmalıdır $(2,3)$. Boşanma, kayıp, göç, afet, çocuğun hasta olması, hastanede yatma ya da aile üyelerinden birinin ölümcül hastalık tanısı alması ailede strese neden olabilir (4). Bu tür stresli durumlarda ve sonrasinda aile devamlılığının sağlanması, birlik duygusunun pekiştirilmesi ve yeni çözümler üretebilmeleri için aile üyelerinin desteklenmesi gerekir. Ailenin güçlendirilmesi (AG), aileleri stresli dönemlerinde destekleyen ve koruyan ilişki/süreç dizisi olarak tanımlanır (5). Ailenin gücünü ortaya çıkarmayı amaçlayan $A G$ yaklaşımı, fiziksel/duygusal acının azalması için aile bireylerini destekler, farklı baş etme yöntemleri bulmalarına yardımcı olur ve aile işlevinin devamlılığına katkı sağlar (4-6). Hemşireler, stresli zamanlarda aile üyelerinin gereksinimlerini karşılamalı, baş etmelerine, umutlarını sürdürmelerine, bilgiye ve kaynaklara ulaşmalarına yardımcı olmalı ve aile işlevselliğini desteklemelidir (5-7).

\section{Çocuğu Hastanede Yatan Ailenin Güçlendirilmesi}

Hastalık ve hastanede yatma çocuk ve ailesi için stres yaratan bir deneyimdir $(8,9)$. Bu durumla karşılaşan aile bireyleri fizyolojik, psikolojik ve sosyal olarak etkilenebilirler (1). Çocukları hastaneye yatan ebeveynler, çocuğun hasta olması, ona ne olacağını bilememe, farklı bir ortamda bulunma, kişisel ihtiyaçlarını karşılayamama, bakım verici rolünü sürdürememe, hastanedeki rollerini tam olarak anlayamama ve ekonomik zorluklar yaşama gibi birçok nedenden dolayı anksiyete yaşayabilirler. Aynı zamanda hastanede olma çocuğun anksiyetesini arttırırken, aile bütünlüğünün ya da işlevselliğinin bozulmasına neden olabilir. Ailenin anksiyetesinden hasta çocuk da etkilenerek iyileşme süreci gecikebilir (1). Pediatri hemşirelerinin ailenin güçlendirilmesi yaklaşımını tanımaları, yararlarının farkında olmaları ve bakımlarında kullanarak aileleri desteklemeleri, çocuk ve ailenin iyilik halini sürdürmelerine katkı sağlayabilir.

Pediatri hemşiresinin bakım verdiği çocuk ve ailenin gücünü anlayabilmesi için ayrıntılı veri toplaması gerekir. Geliri ve eğitim düzeyi düşük, stresi yüksek, iletişim sorunu yaşayan, aile bağları zayıf, sosyal desteği yetersiz olan, sağlık hizmetlerinden ve sosyal yardım kuruluşlarından az yararlanan ailelerin daha fazla güçlendirilmeye gereksinimleri vardır $(10,11)$. Pediatri hemşirelerinin risk grubundaki aileleri tespit etmesi ve güçsüzlük yaşadıkları durumlarda güç kazanmaları için desteklemesi önemlidir.

*Araş. Gör. Aydın Adnan Menderes Üniversitesi, Hemşirelik Fakültesi, Çocuk Sağlığı ve Hastalıkları Hemşireliği AD. Efeler/Aydın. e-posta: Pelin.karatas@adu.edu.tr Orcid No: 0000-0001-9170-115X, ** Prof. Dr. Aydın Adnan Menderes Üniversitesi, Hemşirelik Fakültesi, Çocuk Sağlığı ve Hastalıkları Hemşireliği AD. Efeler/Aydın. Orcid No: 0000-0001-5440-5431, *** Dr. Öğretim Üyesi. Aydın Adnan Menderes Üniversitesi, Hemşirelik Fakültesi, Çocuk Sağlığı ve Hastalıkları Hemşireliği AD. Efeler/Aydın. Orcid No: 0000-0002-9039-5637 
Güçlendirilme, kişinin çevresindeki durumları yönetebilmeleri için gerekli olan içsel gücün ortaya çıkarılması sürecidir (12). AG sürecinde ebeveynin, diğer aile üyelerinin ya da çocuğun bir konuya yönelik sistematik bir şekilde yeterlilik kazanması sağlanır. Ailenin güçlendirilmesi kavram olarak pediatri hemşirelerinin rolleri arasında açıkça yer almamaktadır fakat pediatri hemşireleri ailenin güçlendirilmesini eğitim ve danışmanlık rolleri kapsamında sürdürmektedirler (1). Ülkemizde ailenin güçlendirilmesine ilişkin özel program bulunmamaktadır fakat pediatri hemşiresinin sistematik olarak planladığı bütün eğitim ve danışmanlık faaliyetleri bu kapsamda yer almaktadır. Hemşireler, aileyi güçlendirmek için bireysel/grup güçlendirme destek programlarını oluşturarak işe başlayabilirler ve bu tür ailelerle karşılaştıklarında bu programları uygulamaya koyabilirler $(12,13,15-17,19)$. Ailenin güçlendirilmesi sağlıklı, önlem alınmazsa sağlığı bozulabilecek ya da hasta çocukların ebeveynlerine uygulanabilir. Yapılan çalışmalarda ailenin güçlendirilmesinin sonucunda ebeveynlerin depresyon ve stres düzeyinin azaldığı, aile işlevinin, öz-yeterliğinin, otonomisinin, problem çözme becerilerinin ve aile üyelerinin birbirlerine olan desteğinin arttığı gösterilmiştir $(12,13,16,19)$. Ayrıca ebeveynlerin çocuklarına daha nitelikli bilgi verdikleri, bakımı yönetme becerilerinin arttığı ve çocukların hastaneye yatış sayılarının azaldığ́ ekle belirlenmiştir (17- 19). Ailenin güçlendirilmesine ilişkin yapılan çalışmalar Tablo-1 de verilmiştir.

Tablo 1. Ailenin Güçlendirilmesi Programları ile ilgili Yapılan Çalışmalar

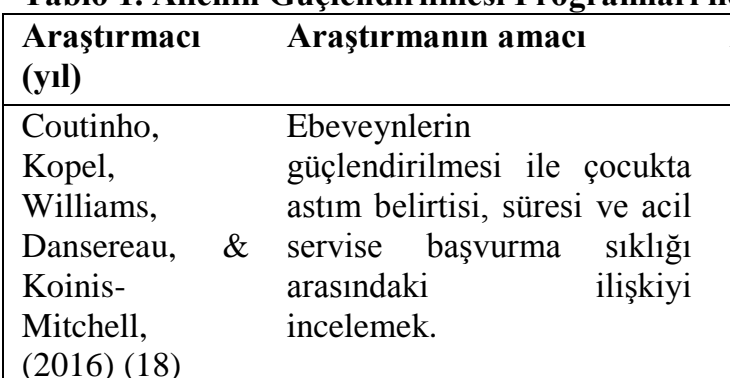

\section{Araştırma tipi; örneklem; Sonuç sonuç değişkeni}

Tanımlayıcı çalışma; 130 Ebeveyni daha güçlü olan çocuklar astım ebeveyn çifti; Çocuğun nedeni ile daha az hastaneye başvurmuştur. astım semptomları ile aile güçlendirme ölçek puanı.

(2016) (18)

Yeh, Ma, Astımlı çocuğu olan ailelere Huang, Hsueh, uygulanan güçlendirme \& Chiang, programının aile işlevlerine (2016) (13) ve astımlı çocukların solunum fonksiyonuna olan etkisini incelemek.

Rat

\begin{tabular}{|lll}
\hline Liu et & al., & Prematüre bebeği olan ve \\
$(2010)(12)$ & güçlendirme programı \\
& uygulanan ebeveynlerin \\
& taburculuk sonrası \\
& öz-yeterlik, algılanan stres \\
& ve depresyon durumlarını \\
& incelemek.
\end{tabular}

Wakimizu, Gelişimsel yetersizliği olan

Yamaguchi, \& çocukların ailelerinin yaşam

Fujioka, (2017) koşullarını değerlendirmek, (14) ailenin güçlendirilmesi ve ebeveynlerin yaşam kalitesi ile ilişkili faktörleri araştırmak.

\begin{abstract}
Randomize Kontrollü Güçlendirme programı uygulanan ailelerin Çalışma (RKÇ); 34 ebeveyn standart bakım alanlara göre ebeveynlerin çifti; Ebeveyn stres ölçek stresi azalmış, aile işlevleri ve çocukların puanı, aile güçlendirme solunum fonksiyonu artmıştır.
\end{abstract}

ölçek puanı ve çocukların solunum fonksiyon testi sonucu.

RKÇ; Çalışma grubu, 35 ebeveyn çifti ve kontrol grubu, 35 ebeveyn çifti; Ebeveynlerin öz-yeterlik, algilanan stres ve depresyon ölçek puanları.

Kesitsel çalışma; 93
ebeveyn; Aile güçlendirme ve yaşam kalitesi ölçek puan1.

Program sonunda ebeveynlerin depresyon ve algılanan stres düzeyi azalmış, özyeterliği artmıştır.

Gelişimsel yetersizliği olan çocukların ebeveynlerinin aile güçlendirmesi ve yaşam kalitesi puan ortalamaları düşük düzeydedir.
Wakimizu ve Motor ve zihinsel engelli ark. (2018) (10) çocuğa bakım veren ailelerin güçlenmesini etkileyen faktörleri belirlemek.
Kesitsel çalışma; 1362 bakım verici; Aile güçlendirme ölçek puanı.
Bakım vericinin yaşının ve öğrenim durumunun artmas1, çevresel desteğinin yeterli olmas1, ev ziyareti sistemini yeterli kullanması, kurum desteği alması, gelir düzeyinin yüksek ve aile bağının güçlü olması, aile güçlendirme puanını olumlu yönde etkilemiştir.

\begin{tabular}{|c|c|c|}
\hline $\begin{array}{l}\text { Han, Yang, \& } \\
\text { Hong, }(2018) \\
(11)\end{array}$ & $\begin{array}{l}\text { Özel gereksinimi olan } \\
\text { çocuklarin } \\
\text { gücünü belirlemek. }\end{array}$ & 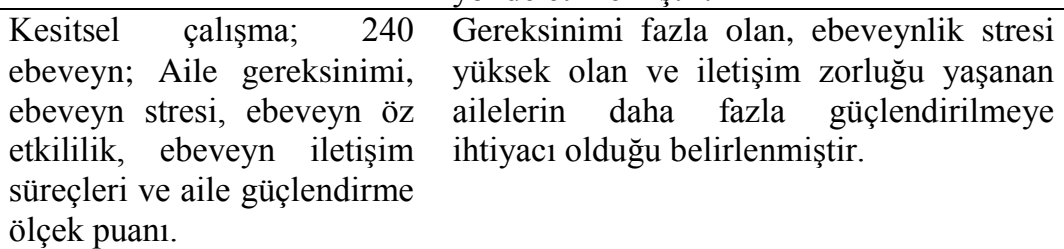 \\
\hline
\end{tabular}




\begin{tabular}{|c|c|c|c|}
\hline $\begin{array}{l}\text { Wacharasin, } \\
\text { Phaktoop, \& } \\
\text { Sananreangset } \\
\text { al.( 2015) (17) }\end{array}$ & $\begin{array}{lr}\text { Talasemili } & \text { çocukların } \\
\text { ailelerine uygulanan aile } \\
\text { güçlendirme programının } \\
\text { etkinliğini değerlendirmek. }\end{array}$ & Kalitatif çalışma; 25 aile. & $\begin{array}{l}\text { Programa katılan ebeveynler çocuklarına } \\
\text { daha iyi bilgi verdiklerini ve bakımı } \\
\text { yönetme becerilerinin artığını } \\
\text { belirtmişlerdir. Ayrıca aile olarak daha } \\
\text { sağlıklı ve güçlü karar verdiklerini, aile } \\
\text { üyelerinin birbirlerine desteğinin arttığını, } \\
\text { ailenin işleyişi, yönetimi ve aile içi } \\
\text { ilişkiler hakkında bilgi paylaşımının } \\
\text { arttığını bildirmişlerdir. }\end{array}$ \\
\hline $\begin{array}{l}\text { Herbert, } \\
\text { Gagnon, } \\
\text { O’Loughlin, \& } \\
\text { Rennick, (2011) } \\
(15)\end{array}$ & $\begin{array}{l}\text { Ebeveynlerin ev ortamında } \\
\text { sigara içmesini önlemek için } \\
\text { uygulanan güçlendirme } \\
\text { programının } \\
\begin{array}{l}\text { değerlendirmek. } \\
\text { etkinliğini }\end{array}\end{array}$ & $\begin{array}{l}\text { RKÇ; } 30 \text { aile; } \begin{array}{r}\text { Ebeveyn } \\
\text { güçlendirme ve nikotin }\end{array} \\
\text { bağımlılığ1 ölçek puanı ile } \\
\text { evde sigara içme özellikleri. }\end{array}$ & $\begin{array}{l}\text { Bu programın ev ortamında sigara } \\
\text { içilmesini önlemeye yönelik etkisinin } \\
\text { olmadığ1 saptanmıştır. Ancak müdahale } \\
\text { grubunda kontrol grubuna göre ev } \\
\text { ortamında sigara içilmesi azalmıştır. }\end{array}$ \\
\hline $\begin{array}{l}\text { Fadda, } \\
\text { Galimberti, } \\
\text { Carraro, \& } \\
\text { Schulz, (2016) } \\
(16)\end{array}$ & $\begin{array}{l}\text { Kızamık-Kızamıkçık- } \\
\text { Kabakulak aşısını düşük } \\
\text { oranda yaptıran bölgedeki } \\
\text { ebeveynlere güçlendirme } \\
\text { programı uygulayarak aşıya } \\
\text { yönelik karar vermelerini } \\
\text { değerlendirmek. }\end{array}$ & $\begin{array}{lll}\text { Kalitatif } & \text { çalışma; } & 30 \\
\text { ebeveyn. }\end{array}$ & $\begin{array}{l}\text { Aile güçlendirmesi programı, ebeveynlerin } \\
\text { otonomilerini destekleyerek karar verme } \\
\text { sürecine aktif katılımlarını sağlamak için } \\
\text { uygulanabilir. }\end{array}$ \\
\hline $\begin{array}{l}\text { Dönmez, } \\
\text { (2018) (19) }\end{array}$ & 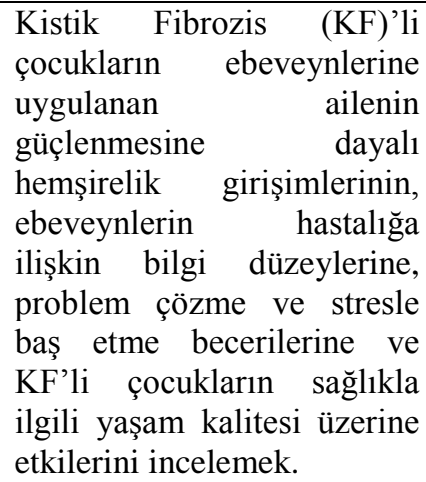 & $\begin{array}{l}\text { RKÇ; } 24 \text { deney ve } 24 \\
\text { kontrol grubu; Ebeveynlere } \\
\text { ilişkin hastalık bilgi } \\
\text { değerlendirme, problem } \\
\text { çözme envanteri, stresle başa } \\
\text { çıkma tarzları ve KF'li } \\
\text { çocuklarda sağlıkla ilgili } \\
\text { yaşam kalitesi ölçek puanı. }\end{array}$ & $\begin{array}{l}\text { Ailenin güçlenmesine dayalı hemşirelik } \\
\text { girişimleri uygulanan ebeveynlerin } \\
\text { diğerlerine göre hastalığa ilişkin bilgi } \\
\text { düzeyi artmış, problem çözme becerileri } \\
\text { ve çocukların sağlıkla ilgili yaşam kalitesi } \\
\text { artmıştır. }\end{array}$ \\
\hline
\end{tabular}

\section{Să̆lık Bakımında Ailenin Güçlendirilmesinin Yararları}

AG, ailenin sağlık bakımında karşılaştı̆̆ı sorunlara çözüm bulmaları için karar verme sürecinde onları destekler, iç ve dış güç kaynaklarına yönelik farkındalık kazandırır, aile bütünlüğünün ve işlevselliğinin korunmasına yardımcı olur (20). Pediatri hemşiresi, aile hakkında veri toplarken mutlaka ailenin iç ve dış güç kaynaklarını öğrenmelidir. Ailenin iç güç kaynakları arasında aile bağları, aile içi ilişkileri, ekonomik durumları ve baş etme yöntemleri vardır. Ailenin dış güç kaynakları arasında ise sosyal çevreleri ve onlarla olan ilişkileri bulunur (5). Hemşire bu konularla ilgili veri toplamaya başladığında güçlendirme hareketini de başlatmış olur (21). Bu bağlamda ailenin güçlenmesinin sağlık bakım sürecindeki yararları;

- Ailenin hastanede yatan çocuğun bakımında aktif rol almasını sağlar,

- Çocuğun otonomisini ve kararlara katılımını destekler,

- Ailenin stresini azaltır ve etkili baş etmesini sağlar,

- Aile stresinin azalmasıyla çocuğun iyilik hissi artar,

- Ailenin mantıklı ve duruma özgü karar verebilmesini destekler,

- Ailenin sağlık personeli ile uyum içerisinde çalışmasını sağlar ve onları rakip olarak görmesini önler,

- $\quad$ Ailenin hastane dışındaki sorumluluklarını yerine getirmesini destekler $(4,22,23)$.

Yapılan çalışmalarda, ebeveynlerin bilgi sahibi olmadığı durumlarda yeterlilik kazanmaları için bilgi verilmesinin olumlu sonuçlar sağladığı belirlenmiştir $(24,25)$. AG'nin olumlu etkilerinin ortaya çıkabilmesi için pediatri hemşirelerinin bu yaklaşımın bileşenlerini bilmesi ve uygulamalarında kullanması gerekir.

\section{Ailenin Güçlendirilmesi Yaklaşımının Bileşenleri}

AG'nin bileşenleri insancıl, çocuk ve aile odaklı bir sağlık sistemi yaratmayı amaçlar. AG'nin dört temel bileşeni vardır; Aile merkezli bakım: Hastayı ve aileyi bakımın merkezine yerleştirir.

Güçlendirme: Kişileri hedeflerine ulaşmaları ve yeni hayat amacı edinmeleri için destekler.

Sağlı ̆̆ geliştirme: Hastayı ve ailesini kendi bakımlarına katılması için cesaretlendirir ve sorumluluk almalarını sağlar.

İşbirliği: Hasta ve ailesi ile bakım vericiler arasında işbirliğine dayalı bir ilişki sağlar $(5,22)$.

Bu bileşenler birbirinden farklı gibi görünse de uygulamada birçok ortak noktası vardır. Bunlar:

- Sağlık personeli ile çocuk ve aile arasındaki gücü dengelemek, 
- Sağlık personelinin çocuğa ve ailesine odaklanmasını sağlamak,

- Sağlık ve sağlık bakımı kararının çocuk ve ailesi tarafından verilmesini desteklemek,

- Çocuk ve ailenin haklarına saygı duymak,

- Her ailenin güçlü yönlerinin olduğunu bilmek ve bunu ortaya çıkarmak,

- Ailenin baş etmesini desteklemek,

- Hastalıktan sağlığa geçişi kolaylaştırmak,

- Sağlık bakımında hastalığa odaklanmak yerine güçlendirmeye odaklanmak.

\section{Ailenin Güçlendirilmesinin Hemşireler Tarafindan Uygulanması}

Hemşirelik bakımında ailenin güçlendirilmesi yaklaşımını kullanabilmek için gereken ilk adım, hemşire ile hasta/aile ilişkisinin saygı ve güvene dayalı olmasıdır $(5,22)$. Hemşireler, aileyi dinler $(26)$, karşılıklı olarak görüşlerini tartışırlar $(26,27)$ ve onlara profesyonel önerilerini sunarlar (3). Bu adımda ebeveynlerle, hemşireden ne bekledikleri, ne yapmalarını istedikleri ve kendilerinin bakımda ne kadar yer almak istediği mutlaka konuşulmalıdır. Bu konuşma aile ve hemşire arasındaki güven ilişkisinin oluşmasına ve sınırların belirlenmesine yardımcı olur. Bu sayede hemşire ve ebeveyn arasındaki rol karmaşası giderilir, kafa karışıklığını önlenir ve çift yönlü memnuniyet sağlanır. İkinci adım, aileyle bağ kurmaktır. Bu adımda hemşire aile ile fiziksel ve duygusal olarak yakın olmalıdır. Hemşire sadece sorun varlığında ailenin yanında olduğunda zaman, aile kendini açacak kadar hemşireyi yakın hissetmeyebilir. Sorunlar dışında da aile ile bağ kuran ve onları destekleyen hemşireler aileye duygusal olarak daha yakın olabilir. Böylece ailenin hemşireye olan güveni artar. Hemşireyi sadece çocuğa bakım veren sağlık personeli konumundan çıkarır ve aile hemşirenin varlığını tam anlamıyla hissedebilir. Hemşire aileyle kurduğu bu özel bağ sayesinde aile bireylerinin kendilerini ifade etmesini kolaylaştırır ve hatta farkında olmadıkları güçsüz yönlerini keşfetmelerini sağlayabilir $(21,28)$. Kurulan bağın sonucunda aile güçsüz yönlerini fark eden aile bireyleri hemşireden yardım isteyebilir. Böylece hemşire ailenin güçsüz olduğu alanları tanımlar, baş etme yöntemlerini değerlendirir ve güçlü yönlerinin ortaya çıkmasına yardımcı olur $(5,7,21,22)$. Hemşire tarafından ailenin önceliğinin belirlenmesi ve bunlara yönelik bakımın planlanması ise üçüncü adımı oluşturur $(5,29)$.

Hemşireler hasta bakımında yetersizliğe/eksikliğe (eksiklik temelli bakım) odaklanmak yerine çocuğun ve ailenin güçlü yönlerini ortaya çıkaran bakım sağladıklarında güçlendirme temelli bakımı başlatmış olurlar. Eksiklik temelli bakım ile güçlendirme temelli bakımın ayırt edici özellikleri Tablo-2'de verilmiştir (5).

Tablo 2. Eksiklik Temelli Bakım ile Güçlendirme Temelli Bakım Arasındaki Farklar

\begin{tabular}{|c|c|c|}
\hline $\begin{array}{l}\text { Ayırt Edici } \\
\text { Özellikler }\end{array}$ & Eksiklik Temelli Bakım & li Bakım \\
\hline Amaç & $\begin{array}{l}\text { Hastaya sadece hastalık tanısına göre standart bakım } \\
\text { verir. Hastanın, tedavi kararlarını koşulsuz kabul } \\
\text { etmesini ister. }\end{array}$ & $\begin{array}{l}\text { Hemşire bireyin sahip olduğu yeteneğe } \\
\text { odaklanır. Bireyi damgalamaz. Güvene dayalı } \\
\text { ilişki kurar ve onu destekler. }\end{array}$ \\
\hline İçerik & $\begin{array}{l}\text { Hemşire için sadece hastalık önemlidir ve hastalığın } \\
\text { tedavisine odaklanır. Hastanın yaşadığı olası bir } \\
\text { sorun varlığıla ilgilenmez. }\end{array}$ & $\begin{array}{l}\text { Hemşire, var olan sorunla birlikte kişinin sağlık } \\
\text { ve hastalık durumunu, duygularını, endişelerini, } \\
\text { deneyimlerini, aile içi ilişkilerini, sosyal, } \\
\text { kültürel ve ekonomik durumunu dikkate alır. }\end{array}$ \\
\hline Kavramlar & $\begin{array}{l}\text { Olumsuz kavramlar yer alır (hastalık, işlev } \\
\text { bozukluğu, yetersizlik ve eksiklik gibi). Hastaya } \\
\text { sürekli olumsuz mesaj verilir. }\end{array}$ & $\begin{array}{l}\text { Olumlu kavramlar yer alır (güç, enerji, değişim } \\
\text { ve firsatlar gibi). Hastayı destekleyen mesajlar } \\
\text { verilir. }\end{array}$ \\
\hline İliş̧ki & $\begin{array}{l}\text { Geleneksel ve paternalist yaklaşım vardır. Hasta ve } \\
\text { ailesinin pasif rolde olması istenir. }\end{array}$ & $\begin{array}{l}\text { Sağlık ekibi, hasta ve aile birlikte çalışırlar. } \\
\text { Beraber karar alırlar, plan oluştururlar ve } \\
\text { birlikte çözüm bulmaya çalışırlar. }\end{array}$ \\
\hline $\begin{array}{l}\text { Birincil Veri } \\
\text { Kaynakları }\end{array}$ & $\begin{array}{l}\text { Hemşireler, laboratuvar testleri, biyopsiler, röntgen } \\
\text { filmleri gibi objektif verilere odaklanırlar. Hasta ve } \\
\text { ailesinin düşünceleri, deneyimleri ve duyguları } \\
\text { önemli değildir. }\end{array}$ & $\begin{array}{l}\text { Bireyin ve ailenin düşünceleri, deneyimleri, } \\
\text { duyguları gibi öznel veriler ile objektif veriler } \\
\text { beraber kullanılır. }\end{array}$ \\
\hline $\begin{array}{l}\text { Bakımın } \\
\text { Planlanması }\end{array}$ & $\begin{array}{l}\text { Hemşire, bakımını tanıya yönelik uygular. Aynı } \\
\text { tanıya sahip çocuklar için aynı bakımı planlar. } \\
\text { Hemşirelerin bağımsız rolü sınırlıdır. }\end{array}$ & $\begin{array}{l}\text { Hemşire, bakımını çocuk ve ailesine özgü } \\
\text { planlar. Onların güçlü yönlerini ortaya } \\
\text { çıkarmaya çalışır. Çocuk ve ailesinin her sorunu } \\
\text { için ayrı girişimler uygular. }\end{array}$ \\
\hline Çıktılar & Bakım verenler hastalığın tedavisine odaklanır. & $\begin{array}{l}\text { Çocuk ve ailenin iyi olma, yaşam kalitesi, gücü, } \\
\text { güçlenmesi değerlendirilir. Çocuk ve ailesini } \\
\text { güdülemeye çalışır. Çocuk ve ailesinin } \\
\text { enerjisini, farkındalıklarını ve umutlarını } \\
\text { arttırmaya çalışır. Sağlık personeli ve ailenin } \\
\text { doyumu artar. }\end{array}$ \\
\hline
\end{tabular}


Hemşireler, akut veya kronik hastalık nedeniyle kriz yaşayan ailelerin, krizi yönetmelerine ve baş etmelerine yardımcı olmayı amaçlar (3).

Pediatri hemşirelerinin AG kapsamında uygulayabileceği girişimler aşağıda sıralanmıştır:

- Pediatri hemşireleri aile özelliklerini tanımalıdır. Aile üyelerinin birbirleri/ başkaları ile olan iletişim şekilleri, boş zamanı değerlendirme biçimleri, birlikte geçirdikleri zamanlar, ebeveynlik stilleri/stratejileri, ev içi rutinleri ve kriz durumunda gösterdikleri tepkiler sorgulanmalıdır (5).

- Pediatri hemşireleri, ailelerin gücünü ortaya çıkarmak için aile ile birlikte iç ve dış kaynaklarını tartışmalı ve onlara rehberlik etmelidir (30).

- Pediatri hemşireleri, aile ile her konuyu tartışabilmelidir (1).

- Ebeveynler, çocuklarını en iyi tanıyan ve onlar için en iyisini isteyen kişilerdir (1). Ebeveynler, çocukları hasta olduğunda veya hastaneye yattığı zamanlarda rol karmaşası yaşayabilirler. Bu durum ebeveynlerin anksiyetelerini arttırır ve çocukları için doğru karar vermelerini zorlaştırabilir. Pediatri hemşireleri ebeveynlerde anksiyete yaratan durumları onlarla tartışabilmelidirler $(1,31)$.

- Pediatri hemşirelerinin, bakım ve tedavinin her aşamasında ebeveynin ve çocuğun onayını alması gerekir. Böylece hem çocuğun hem de ebeveynin gücü desteklenir (30).

- Pediatri hemşirelerinin ailelere bu yaklaşımı anlatması, ailelerin sağlık bakımında sadece çocuğun değil kendilerinin de önemli olduğunu hissetmelerini sağlar (5).

Güçlendirme temelli hemşirelik yaklaşımını kullanmak, hasta ve ailesinin olduğu kadar pediatri hemşirelerinin de güçlenmesine katkı sağlar.

\section{Ailenin Güçlendirilmesinin Hemşirelere Katkısı}

Uygulamalarında bu yaklaşımı kullanan hemşireler, bakımlarında sadece hastalığa odaklanmayıp bakımın merkezine çocuk ve aileyi alırlar (32,33). AG, sayesinde hemşirelerin, hasta ve ailesiyle aralarında güven ve saygıya dayalı ilişki oluşur; hemşireler, onların duygularını, düşüncelerini, hayallerini, gelecek hedeflerini tartışabilirler ve onları farklı çözüm yolları geliştirmeleri için cesaretlendirirler $(3,26,34)$. Bu durum hemşirelerin, hastaları ile özel bir bağ kurmasını, mesleğinden keyif almasını ve yaşamdan doyum almasını sağlar (5). AG yaklaşımı hemşirelerin, hasta ve ailesi hakkında daha kapsamlı veri toplamasını sağlar $(5,7,22)$. Bu sayede hemşirelerin uygulama ve etki alanları genişler $(5,34)$.

\section{Sonuçların Uygulamada Kullanımı}

AG, hemşirelik bakımında hasta ve ailesinin güçlü yönlerini ortaya çıkarır ve güçsüz yönlerini güçlendirmeyi sağlar. Hasta çocuk ve ailesinin emosyonel durumları birbirinden etkilenmektedir. Bu bağlamda aile üyelerinin güçlenmesi, çocuğun iyileşme sürecine olumlu katkı sağlayabilir. Çocuk ve ailelerin ise kendilerini bakımda güçlü hissetmelerine, otonomilerinin artmasına, yetersiz oldukları konuda bilgi sahibi olmalarına, bakım memnuniyetinin artmasına, aile bağının devam ettirilmesine ve yeni baş etme yöntemleri geliştirmelerine yardımcı olur. AG'yi bakımlarında kullanmak, pediatri hemşirelerinin hasta ve ailesiyle iletişimini güçlendirir ve hemşirenin mesleki ve/veya yaşam doyumlarını arttırabilir. Pediatri hemşirelerinin, ailenin güçlü ve güçsüz yönlerini belirlemesi, güçlü yönlerini ortaya çıkarması ve güçsüzlük yaşadıkları durumlarda güç kazanmalarını desteklemesi önerilir. Pediatri hemşirelerinin, ailenin güçlü ve güçsüz yönlerini belirlemesi, güçlü yönlerini ortaya çıkarması ve güçsüzlük yaşadıkları durumlarda güç kazanmalarını desteklemesi önerilir.

\section{Bilgilendirme}

Yazarların Katkı Beyanı: Fikir/Kavram: PK, HÇ, SSK, Tasarım: PK, HÇ, SSK, Denetleme/Danışmanlık: PK, HÇ, SSK, Kaynak Taraması: PK, HÇ, Makalenin Yazımı: PK, HÇ, SSK, Eleştirel Düşünme PK, HÇ, SSK şeklindedir. Yazarlar arasında herhangi bir çıkar çatışması yoktur. Ayrıca sorumlu olduğumuz araştırmada herhangi bir firma ile çıkar ilişkisi de bulunmamaktadir.

\section{Kaynaklar}

1. Hockenberry MJ, Wilson D, Rodgers CC. The Child Who Is Hospitalized.In Wong's Essentials of Pediatric Nursing-EBook, 10 ${ }^{\text {th }}$ ed:864-83. Canada, Elsevier Health Sciences, 2016.

2. Jones TL, Prinz RJ. Potential roles of parental self-efficacy in parent and child adjustment: A review. Clin Psychol Rev. 2005;25(3):341-63.

3. Roberts SK, Crawford PA. Literature to help children cope with family stressors. Young Children. 2008;16:12-7.

4. Kieckhefer GM, Trahms CM, Churchill SS, Kratz L, Uding N, Villareale N. A randomized clinical trial of the building on family strengths program: an education program for parents of children with chronic health conditions. Matern Child Health J. 2014;18(3):563-74.

5. Gottlieb LN. Strengths-based nursing care: Health and healing for person and family. $1^{\text {st }}$ ed. New York, Springer Publishing Company, 2013.

6. Defrain J, Jones JE, Skogrand L, Defrain N. (2003). Surviving and transcending a traumatic childhood: An exploratory study. Marriage \& Family Review. 2003;35(1-2):117-146. 
7. Registered Nurses Association of Ontario (RNAO). The nursing best practice guideline: Supporting and Strengthening Families Through Expected and Unexpected Life Events. 2006. Available from: www.rnao.org Accessed:10.11.2018

8. Francischinelli AGB, Almeida FDA, Fernandes DMSO. Routine use of therapeutic play in the care of hospitalized children: nurses' perceptions. Acta Paulista de Enfermagem. 2012;25(1):18-23.

9. Li WH, Chung JOK, Ho KY, Kwok BMC. Play interventions to reduce anxiety and negative emotions in hospitalized children. BMC Pediatr. 2016;16(1):36.

10. Wakimizu R, Fujioka H, Nishigaki K, Matsuzawa A. Family empowerment and associated factors in Japanese families raising a child with severe motor and intellectual disabilities. Int J Nurs Sci. 2018;5(4):370-376.

11. Han KS, Yang Y, Hong YS. A structural model of family empowerment for families of children with special needs. J Clin Nurs. 2018;27(5-6):e833-44.

12. Liu CH, Chao YH, Huang CM, Wei FC, Chien LY. (2010). Effectiveness of applying empowerment strategies when establishing a support group for parents of preterm infants. J Clin Nurs. 2010;19(11 - 12):1729-37.

13. Yeh HY, Ma WF, Huang JL, Hsueh KC, Chiang LC. Evaluating the effectiveness of a family empowerment program on family function and pulmonary function of children with asthma: a randomized control trial. Int J Nurs Stud. 2016;60:133144.

14. Wakimizu R, Yamaguchi K, Fujioka H. Family empowerment and quality of life of parents raising children with developmental disabilities in 78 Japanese families. Int J Nurs Sci. 2017;4(1):38-45.

15. Herbert RJ, Gagnon AJ, O’Loughlin JL, Rennick JE. Testing an empowerment intervention to help parents make homes smoke-free: a randomized controlled trial. J Community Health. 2011;36(4):650-7.

16. Fadda M, Galimberti E, Carraro V, Schulz PJ. What are parents' perspectives on psychological empowerment in the MMR vaccination decision? A focus group study. BMJ Open. 2016;6(4):e010773.

17. Wacharasin C, Phaktoop M, Sananreangsak S. Examining the usefulness of a Family Empowerment Program guided by the Illness Beliefs Model for families caring for a child with thalassemia. J Fam Nurs. 2015;21(2):295-321.

18. Coutinho MT, Kopel SJ, Williams B, Dansereau K, Koinis-Mitchell D. Urban caregiver empowerment: Caregiver nativity, child-asthma symptoms, and emergency-department use. Fam Syst Health. 2016;34(3):229-39.

19. Dönmez H. (2018). Kistik Fibrozisli Çocukların Ebeveynlerine Uygulanan Aile Güçlendirmeye Dayalı Hemşirelik Girişimlerinin, Ebeveynlerin Stresle Baş etme, Problem Çözme Ve Çocukların Yaşam

20. Kalitesi Üzerine Etkisi: Randomize Kontrollü Çalışma. Doktora Tezi. Konya: Selçuk Üniversitesi.

21. Brown SL. Family structure transitions and adolescent well-being. Demography. 2006;43(3):447-61.

22. Sittner BJ, Hudson DB, Defrain J. Using the concept of family strengths to enhance nursing care. MCN Am J Matern Child Nurs. 2007;32(6):353-7.

23. Feeley N, Gottlieb LN. Nursing approaches for working with family strengths and resources. JFN. 2000;6(1):9-24.

24. Walsh F. Traumatic loss and major disasters: Strengthening family and community resilience. Fam Process. 2007;46(2):207-27.

25. Dias RB, Boery RNSDO, Vilela ABA. Knowledge of nurses and incentive strategies for family participation in breastfeeding. Ciencia \& saude coletiva. 2016;21(8):2527-36.

26. Duffy LV, Vessey JA. A Randomized Controlled Trial Testing the Efficacy of the Creating Opportunities for Parent Empowerment (COPE) Program for Parents of Children with Epilepsy and Other Chronic Neurological Conditions. J Neurosci Nurs. 2016;48(3):166-174.

27. Biag AD. Development and psychometric analysis of a strengths perspective-based instrument on clinical instruction in nursing. J Nurs Educ Pract. (2014);5(2):52-7.

28. Coyle JP. Resilient families help make resilient children. Journal of Family Strengths. 2011;11(1):1-16.

29. Melnyk BM, Crean HF, Feinstein NF, Fairbanks E, Alpert-Gillis LJ. Testing the theoretical framework of the COPE program for mothers of critically ill children: an integrative model of young children's post-hospital adjustment behaviors. J Pediatr Psychol. 2006;32(4):463-74.

30. Coleman CL. Empowered by nurses. Pediatr Nurs. 2016;42(4):193.

31. Trivette C, Dunst C. Community-based parent support programs. Encyclopedia on Early Childhood Development (online). Montreal, Quebec, Centre of Excellence for Early Childhood Development, 2005.

32. Kuo DZ, Houtrow AJ, Arango P, Kuhlthau, KA, Simmons JM, Neff JM. Family-centered care: current applications and future directions in pediatric health care. Matern Child Health J, 2012;16(2):297-305.

33. Adams JA, Anderson RA, Docherty SL, Tulsky JA, Steinhauser KE, Bailey DE Jr. Nursing strategies to support family members of ICU patients at high risk of dying. Heart \& Lung. 2014;43(5):406-15.

34. Attard J, Baldacchino DR, Camilleri L. Nurses' and midwives' acquisition of competency in spiritual care: A focus on education. Nurse Educ Today. 2014;34(12):1460-6.

35. Mokgothu MC, Du Plessis E, Koen MP. The strengths of families in supporting mentally-ill family members. Curationis. 2015;38(1):1-8. 